\title{
The intertwining of vocational aptitude and interest: A study among university students in Indonesia
}

\author{
Ufi Fatuhrahmah a *, Dian Fithriwati Darusmin ${ }^{\text {b }}$, Herlina Siwi Widiana ${ }^{\mathrm{c}}$ \\ Universitas Ahmad Dahlan. Jl. Kapas 9, Semaki, Umbulharjo, Yogyakarta 55166, Indonesia

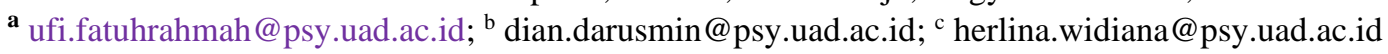 \\ * Corresponding Author
}

Received: 28 September 2020; Revised: 20 October 2020; Accepted: 22 October 2020

\begin{abstract}
Vocational aptitude and interest are the fundamental factors that education and career counsellors utilize to provide suggestions to clients. These concepts are often considered as separate constructs. However, aptitude and interest are interrelated and should both be considered when making career decisions. This study involved as many as 343 university students as participants. Two measurement tools were used: Employee Aptitude Survey (EAS) to measure aptitude and Self-Directed Search (SDS) Holland to measure vocational interest. The data were analyzed using canonical and Pearson product-moment correlation analysis. The findings show that there is a correlation between several types of interest and several types of aptitude. Vocational interest that has the strongest correlation with aptitude was the investigative interest, while the numerical aptitude test has the strongest correlation with interest. In the process of career decision-making, particularly for university students, both aptitude and interest must be taken into consideration, especially the investigative interest and numerical aptitude.
\end{abstract}

Keywords: aptitude; EAS; interest; SDS Holland.

How to Cite: Fatuhrahmah, U., Darusmin, D., \& Widiana, H. (2020). The intertwining of vocational aptitude and interest: A study among university students in Indonesia. Psychology, Evaluation, and Technology in Educational Research, 3(1), 44-52. doi:http://dx.doi.org/10.33292/petier.v3i1.58

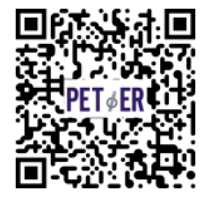

\section{INTRODUCTION}

Cognitive ability and vocational interest are two essential measurement aspects used to see how an individual would differ with another (Pässler et al., 2015) as well as act as the primary source for deciding on future career paths. However, people tend to see aptitude and interest as two unrelated factors. Ackerman and Beier (2003) stated that researchers and academicians tend to view cognitive ability, personality, and interest as entirely independent factors. As an implication, it becomes a challenge to implement knowledge regarding these factors practically. On other hand, reseacrh showed cognitive and non-cognitive aspect provide simultaneously role on academic performance (Handarini, 2019; Komarraju et al., 2013).

Aptitude is described as the potential ability to reflect on one's chance to succeed in completing a task (Snow, 1992). Aptitude reflects a person's condition to reach various achievements and work optimally with the skills and capability that one owns. Aptitude measurement has continuously changed along with the development of the intelligence test. Initially, the design of the aptitude test saw cognitive ability as a single unity (Domino \& Domino, 2006). Next, several aptitude battery tests were developed to measure various components that were also measured in an intelligence test, including other components that were mainly ignored back then, such as mechanical skills (Domino \& Domino, 2006). Leong (2008) exclaimed that the types of aptitude could be categorized into two major areas, namely cognitive and motor. The cognitive aptitude often measured is verbal, numerical, spatial, abstract reasoning, and comprehension ability. Motor ability usually measures motor coordination, finger dexterity, and manual dexterity.

On the other hand, vocational interest is a topic that is not easily defined yet easy to learn (Silvia, 2006). Vocational interest is defined as a pattern of likes, dislikes, and diversity regarding career-related activities or work (Lent et al., 1994; Silvia, 2006). The practical question that rises regarding vocational 
interest is how to identify and measure it. Strong initially developed the vocational interest measurement through the Strong Vocational Interest Blank for Men, based on likes and dislikes regarding various types of jobs. Gradually, studies about vocational interest could be separated into two focus: theoretical (i.e., the structure and development of aptitude, how aptitude influences other variables) and application (i.e., development of measurement tool and vocational interest implementation in counseling) (Silvia, 2006).

Holland's theory has been a dominating vocational interest theory these past few decades (Silvia, 2006). A study by Foutch et al. (2014) that used an application to identify publications found 1970 reference citations for Holland's theory, and it continues to increase to 2318 publications in 2018 (Kennelly et al., 2018). Those publications were divided into five areas: (a) theory application, (b) research and practice in a specific population, (c) tools and instruments to operationalize the theory, (d) RIASEC validity, and (e) specific population studies regarding ethnicity, disability, and social status. There are four basic principles that Holland used to develop the vocational interest theory (Holland, 1985). The first assumption is that people's characteristics are divided into six types: Realistic, Investigative, Artistic, Social, and Enterprising. Each of these types of personality shows a specific personality and behavior. The second assumption is the environment where one lives are also identified into six types of environment model. Third, the interaction between personality and environment could be predicted through past theories. The last assumption stated that some of the results of that interaction are vocational interest, vocational achievement and stability, choice of education, personal competence, and social behavior.

The Holland theory, utilized to develop the SDS Holland, clearly state the overlap between cognitive ability and aptitude. Holland claimed that vocational interest is not only measured based on the specific aptitude that a person has, but also his or her specific skills and competence (Holland, 1985). Several studies implemented this concept by correlating vocational interest with various psychological aspects such as personality (Ludwikowski, 2014), personality and intelligence (Ackerman \& Beier, 2003; Ackerman \& Heggestad, 1997; Carson, 1998a), and aptitude (Arulmani, 2014; Carson, 1998a; Darcy \& Tracey, 2003; Metz \& Jones, 2013). Further, Lowman (1993) created a matric of the correlation profile of Holland's vocational interest with several cognitive abilities. Unfortunately, all these studies were done in a Western context (i.e., America, Europe), and similar research has not been found in Indonesia between 2006 - 2016 (Kennelly et al., 2018).

Other studies that used Holland's concept showed that there are overlaps between cognitive ability, personality, and vocational interest (Ackerman \& Heggestad, 1997). A meta-analysis of 29 studies done by Pässler et al. (2015) showed that there is a strong relationship between cognitive ability and vocational aptitude. They stated that cognitive ability predicts performance because it determines what could be done. Aptitude has the role of directing where those cognitive potentials would be invested. Thus, both factors are needed to optimize one's performance.

Studies that investigate the correlation between SDS Holland profiles with cognitive abilities have used various measurement tools. Based on the meta-analysis by Pässler et al. (2015), seven studies used SDS Holland to correlate with PL-PQ, WAIS-R, BAB, WPT, APM, and ability battery. However, several of these aptitude tests are not available in the Indonesian language. One of the aptitude tests that has been adapted and widely used in Indonesia is the Employee Aptitude Survey (EAS). EAS has been used for more than 50 years in the career and recruitment counselling context (Leong, 2008) and has been claimed to provide a maximum validity per minute during test administration. This test has also been validated in various studies in the Indonesian context (Widiana, 2008, 2012). For that reason, this study aims to explore the relationship between vocational interest and aptitude in the Indonesian context using SDS Holland and EAS among university students.

\section{METHOD}

This study is a quantitative correlational design. Research participants were students of private universities in Yogyakarta from various study programs. The main inclusive criteria are that the participant has never done an aptitude or an interest test before. The total participants involved in this study were 343 people with demographic characteristics described in Table 1. Participants will be subjected to classical testing by trained testers, starting with EAS testing, which is directly followed by filling SDS Holland. A trained scorer does the scoring, which was then double-checked by the supervisor. 
Psychology, Evaluation, and Technology in Educational Research, 3 (1), 2020, 46

Ufi Fatuhrahmah, Dian Fithriwati Darusmin, Herlina Siwi Widiana

Table 1. The Distribution of Study Participants

\begin{tabular}{lcc}
\hline \multicolumn{1}{c}{ Demographic Data } & Frequency & Percentage \\
\hline Sex & & \\
Male & 155 & $45.18 \%$ \\
$\quad$ Female & 188 & $54.82 \%$ \\
Study Program & & \\
$\quad$ Science & 101 & $29.45 \%$ \\
$\quad$ Social Science & 242 & $70.55 \%$ \\
\hline
\end{tabular}

Measurement Tools

Aptitude measurement

Employee Aptitude Survey is a multiple-aptitude battery that has been used widely in career and industrial assessment. EAS includes ten (10) individual subtests that measure different abilities and skills: verbal comprehension (EAS subtest 1), numeric ability (EAS subtest 2), visual pursuit (EAS subtest 3), visual speed and accuracy (EAS subtest 4), space visualization (EAS subtest 5), numerical reasoning (EAS subtest 6), verbal reasoning (EAS subtest 7), word fluency (EAS subtest 8), manual speed \& accuracy (EAS subtest 9), and symbolic reasoning (EAS subtest 10). Psychometric analysis of the Indonesian EAS version reveals the reliability coefficient of each subtest range from .53 to .973 (Widiana, 2008).

Interest measurement

The interest was measured using the Self-Directed Search - Holland (SDS-Holland), used to identify vocational interest as developed by Holland. This self-reported scale has 180 items divided into four parts that measure activity, vocational interest competence, and self-estimation in each of the following interest: Realistic (R), Investigative (I), Artistic (A), Social (S), Enterprising (E), Conventional (C). The total score of the vocational personality types (summary scale) can be achieved by adding all the scores from the sub-sections. The psychometric characteristics of the SDS-Holland were derived from the SDS Manual. The reliability of the scale ranged from .71 to .92 for the section scales and .87 to .92 for the summary scale.

\section{Data analysis}

Canonical correlation analysis and product-moment correlation analysis were applied to explore the correlation between vocational interest and aptitude. Canonical correlation analysis investigates the degree of relationship between two sets of variables (Thompson, 1984). Canonical correlation is an appropriate statistical method to investigate the independent correlation among two or more variable sets (Stevens, 2009). It is because the method honors the reality that all the variables can interact with each other (Thompson, 2005). Canonical correlation analysis provides clear information about the most influential variable to another variable and size effect of each variable. The product-moment correlation was conducted to analyze the relationship of each subtest of EAS and the type of interests from SDS Holland in more detail.

\section{RESULTS AND DISCUSSION}

\section{Results}

The resulting sample was relatively dominant in some interest types: $6.41 \%$ Realistic, $13.11 \%$ Investigative, $10.49 \%$ Artistic, $40.23 \%$ Social, $17.49 \%$ Enterprising, and $12.24 \%$ Conventional. Six functions were derived from the canonical correlation analysis, but only function 1 (one) was signifycant (Sig F = .000), which resulted in a 57.98\% correlation between aptitude and interest (see Table 2). The remaining five functions were not significant, so it was not included in the subsequent statistical analysis.

Further, the canonical weight coefficient shows the contribution of one variate to another. Table 3 in column 1 shows that the dependent variable that influenced the correlation between interest and aptitude the most is Holland I, with a canonic weight score of -.82134. It is followed by Holland R, Holland S, Holland E., Holland E, Holland A and lastly Holland C. 
Psychology, Evaluation, and Technology in Educational Research, 3 (1), 2020, 47

Ufi Fatuhrahmah, Dian Fithriwati Darusmin, Herlina Siwi Widiana

Table 2. Function Derived from Canonical Correlation Analysis Between Aptitude and Interest

\begin{tabular}{ccrrrrr}
\hline Root No & Eigenvalue & \multicolumn{1}{c}{ Pct } & \multicolumn{1}{c}{ Cum Pct } & Canon Cor & \multicolumn{1}{l}{ Sq Cor } & Sig. of F \\
\hline 1 & .22991 & 57.97850 & 57.97850 & .43236 & .18693 & .000 \\
2 & .09659 & 24.35907 & 82.33757 & .29679 & .08809 & .172 \\
3 & .02946 & 7.42993 & 89.76750 & .16917 & .02862 & .875 \\
4 & .02082 & 5.25100 & 95.01850 & .14282 & .02040 & .893 \\
5 & .01296 & 3.26734 & 98.28585 & .11310 & .01279 & .886 \\
6 & .00680 & 1.71415 & 100.00000 & .08217 & .00675 & .812 \\
\hline
\end{tabular}

Table 3. Canonical weight score for vocational interest

\begin{tabular}{cc}
\hline Variable & Canonical Coefficient \\
\hline HOLLAND R & .74508 \\
HOLLAND I & -.82134 \\
HOLLAND A & .09410 \\
HOLLAND S & .17225 \\
HOLLAND E & -.10155 \\
HOLLAND C & -.08854 \\
\hline
\end{tabular}

The descriptive statistical analysis as shown in Figure 1 strengthened the canonical results. Whereby the investigative vocational interest achieved the highest mean score among the aptitude measured in seven of 10 EAS subtests.
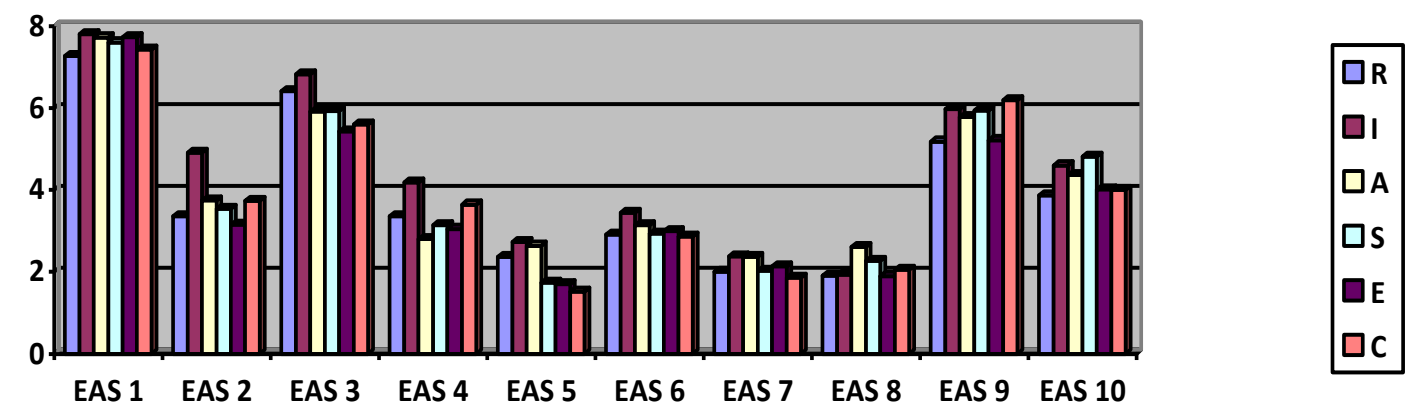

Figure 1. Means of aptitude scores across vocational interest types

Next, canonical weight measurements are used to measure the aptitude variables that most influence interest (see Table 4). The calculation results show that the most influential independent variable in the correlation between aptitude and aptitude is the EAS 2 variable (numerical ability) with a canonical weight of -.72616. This was followed by EAS 4, EAS 7, EAS 9, EAS 5, EAS 3, EAS 8, EAS 10, EAS 1 and lastly EAS 6.

Table 4. Canonical weight score for aptitude

\begin{tabular}{cc}
\hline Variable & Canonical Coefficient \\
\hline EAS1 & .08452 \\
EAS2 & -.72616 \\
EAS3 & .20964 \\
EAS4 & -.41862 \\
EAS5 & .24247 \\
EAS6 & -.05607 \\
EAS7 & -.28893 \\
EAS8 & .20826 \\
EAS9 & -.25300 \\
EAS10 & .15132 \\
\hline
\end{tabular}

Further, canonical loading was measured using the canonical correlation analysis. Canonical loading states the correlation between the variable and variate, in which variables combine in each canonical function and shows an interdependent trait and optimum relationship between variables. At this stage, only function 1 is seen to achieve canonical loading, because no other functions were found to be significant. Only variables that achieve a greater score than $50 \%$ would be included in the analysis. Table 5 depicts that only Holland I (64.8\%) and Holland R (59.9\%) achieve a score greater than 
$50 \%$ in the vocational interest variable. Meanwhile, on the aptitude variable, EAS $2(77.7 \%)$ and EAS 4 $(59.1 \%)$ have the highest loading. Negative values on canonical loading indicate an inverse relationship with their respective variates. Based on canonical loading calculations, it is known that realistic and investigative interests have opposite characteristics. Further results show that individuals with realistic interests tend to get low scores on numerical aptitude and visual speed and accuracy, in contrast to investigative interests that tend to get high scores on both aptitudes.

Table 5. Canonical loading measurement

\begin{tabular}{cc}
\hline Variable & Function 1 \\
\hline HOLLAND R & .59938 \\
HOLLAND I & -.64881 \\
HOLLAND A & .15374 \\
HOLLAND S & .02290 \\
HOLLAND E & .12757 \\
HOLLAND C & -.17009 \\
EAS 1 & -.19510 \\
EAS 2 & -.77796 \\
EAS 3 & -.01549 \\
EAS 4 & -.59120 \\
EAS 5 & -.02809 \\
EAS 6 & -.35938 \\
EAS 7 & -.40425 \\
EAS 8 & -.05141 \\
EAS 9 & -.28872 \\
EAS 10 & .09811 \\
\hline
\end{tabular}

Calculation of correlations between variables used Pearson correlation analysis to see more detailed relationships between variables. This calculation shown in Table 6 indicates that Realistic interest correlates with aptitude expressed in EAS 2 (negative correlation), EAS 4 (negative correlation), EAS 5 (positive correlation) and EAS 9 (negative correlation). Investigative interest correlates with aptitude revealed at EAS 2 (positive correlation), EAS 4 (positive correlation), EAS 5 (positive correlation), EAS 6 (positive correlation), and EAS 7 (positive correlation). Meanwhile, other interests do not correlate with any aptitude expressed by EAS.

Table 6. Pearson Correlation

\begin{tabular}{|c|c|c|c|c|c|c|}
\hline & $\mathrm{R}$ & $\mathrm{I}$ & $\mathrm{A}$ & $\mathrm{S}$ & $\mathrm{E}$ & $\mathrm{C}$ \\
\hline EAS1 & -.021 & .100 & .072 & .053 & .007 & .018 \\
\hline EAS2 & $-.139 * *$ & $.283 * *$ & -.045 & -.015 & -.086 & .028 \\
\hline EAS3 & .103 & .098 & -.089 & -.073 & -.101 & -.085 \\
\hline EAS4 & $-.118 *$ & $.187 * *$ & -.079 & -.030 & -.046 & .069 \\
\hline EAS5 & $.146 * *$ & $.149 * *$ & .002 & -.024 & -.045 & -.016 \\
\hline EAS6 & .012 & $.202 * *$ & .026 & .002 & -.015 & .025 \\
\hline EAS7 & -.085 & $.131 *$ & -.046 & -.014 & .003 & -.042 \\
\hline EAS8 & -.060 & -.014 & -.001 & .031 & -.021 & -.039 \\
\hline EAS9 & $-.129 *$ & .043 & -.020 & .056 & -.020 & .034 \\
\hline EAS10 & .061 & .005 & -.027 & .044 & .026 & .016 \\
\hline
\end{tabular}

** Significant correlation at the .01 level

* Significant correlation at the .05 level

\section{Discussion}

The results indicate that among university students in Indonesia, vocational aptitude and interest are intertwined. The first canonical correlation shows that the maximum correlation between SDSHolland with EAS amounts to $57.98 \%$. Even though the canonical correlation between vocational aptitude and interest is quite high, but the value is smaller than the canonical correlation generated between SDS Holland and the Ball Aptitude Battery scale of 65\% (Carson, 1998b). However, canonical correlation values do not necessarily indicate that there is a substantial share of variance between the SDSHolland and EAS data. Further analysis showed that this correlation received a large contribution from investigative interest. 
Based on the first canonical function, it is known that the investigative interest variate can explain $82 \%$ of the variance in the aptitude component. Several studies have shown that investigative types are quite dominant in spatial, numerical, and verbal abilities (Ackerman \& Heggestad, 1997; Randahl, 1991). Investigative types tend to get high scores on aptitudes associated with general knowledge (Randahl, 1991) and tend to get high scores on each aptitude (Carson, 1996). Investigative type is an individual who shows interest in investigative activities through observation and other systematic and creative ways to understand various phenomena so that this tendency will develop scientific and mathematical competence (Holland, 1985). EAS shows that the measured aptitude is related to cognitive aptitude, and $60 \%$ of the measured aptitude is in the verbal, numerical, and spatial areas. Therefore, this study shows the results of investigative interest in predicting the large number of aptitudes measured by EAS.

From the aptitude side, numerical ability variates can explain $72 \%$ of the variance in the interest component. The results of a meta-analysis conducted by Pässler et al. (2015) showed similar results even though they did not involve studies using EAS. This study shows that numerical abilities have both positive and negative correlations with almost all interests except enterprising interests. That is, the numerical ability possessed by someone is one of the determinants of interest that is built up. Ashton (2018) states that vocational interest is very closely related to feelings of being capable in specific fields.

Canonical loading shows that realistic interest is negatively correlated with investigative interest. However, based on Holland's hexagonal model, these two interests are included in the adjacent category because they are next to each other. This is further strengthened by the comparison of these two interests with numerical and visual speed and accuracy, which are inversely proportional. The main difference between these two types is at the practical-theoretical level; the realistic type has a motoric orientation, while the investigative type has an intellectual orientation (Ackerman \& Heggestad, 1997). Realistic types are indeed described as individuals who tend to like activities that are concrete and practical, so the competencies that are built are technical competencies (Holland, 1985) whereas the numerical and visual speed and accuracy capabilities measured through EAS are purely cognitive. In contrast to individuals who are dominant in investigative interests who view themselves as scholarly and intellectual (Holland, 1985); thus, preferring to develop cognitive and scientific skills. Although these two interests are said to overlap as science and engineering interests (Ackerman \& Heggestad, 1997), they remain to be at different levels.

However, the joint calculations produced by canonical analysis alone are not enough to explain the relationship between each aptitude with vocational interests. The Pearson correlation calculation results show interesting results when looking at the relationship between variables independently. Correlation results on realistic interest show a significant negative correlation with numerical ability, visual speed and accuracy and manual speed and accuracy. These results are in line with the results of Carson (1996), who used aptitude measurement with DAT-A. The results of his study showed that individuals with Realistic interests had low scores on numerical aptitude and clerical speed. The results of this study combined with the study of Carson (1996) show interesting results that realistic interest tends to be weak in terms of aptitude that requires speed (visual), both visually, manually and clerically. The opposite occurs in the correlation between realistic interests with space visualization that is positively and significantly correlated so that it reinforces some of the results of previous studies (Ackerman \& Heggestad, 1997).

Next, investigative interest has a positive and significant correlation with numerical ability, visual speed and accuracy, space visualization, numerical reasoning, and verbal reasoning. This correlation supports interesting findings in previous studies, such as in Carson (1996), which shows that individuals with investigative interests have high aptitude scores for each aptitude except mechanical reasoning.

Artistic, social, enterprising and conventional interests are not predicted by any aptitude as measured by EAS. This is interesting because some studies show that artistic interest is closely related to verbal aptitude (Ackerman \& Heggestad, 1997) and vocabulary (Carson, 1998b). The characteristics of verbal aptitude measured in this study are indeed very different from the verbal aspects measured in the two studies. In EAS, two subtests measure verbal ability, namely EAS 1 (verbal comprehension) and EAS 7 (verbal reasoning) which emphasizes more on understanding language and using language logic, not on mastering vocabulary. This result was also corroborated by Carson (1998b), who stated that artistic interests are indeed more related to abilities related to word creativity and insight. 
Social interest is also not predicted by any aptitude. Similar results were also found by Ackerman and Heggestad (1997). Pässler et al. (2015), who originally estimated social interests correlat-ed with verbal abilities, also did not get results that match their hypotheses. This hypothesis arises because social types tend to choose activities related to others, both in informing, teaching, and developing others (Holland, 1985) so that the competencies that are formed are interpersonal and edu-cational skills that are assumed to be related to verbal aptitude. However, the construct of interpersonal skills is far more complex than just cognitive aptitude-especially verbal, because it focuses more on the skills in interaction and social intelligence which is the ability to understand the feelings, thoughts and behavior of others so that it shows the right response to the situation (Klein, 2009).

Enterprising interest is not predicted by any aptitude measured by EAS. Previous studies found a negative correlation between enterprising interest and ability (Ackerman \& Heggestad, 1997) as well as general knowledge (Carson, 1998a). Another Holland concept (1997) stated that individuals with interest in enterprising are predicted to have good verbal ability that supports their capability to lead and sell. However, a meta-analysis by Pässler et al. (2015) found no evidence to support that claim. Enterprising interest becomes very complex to be defined in terms of cognitive aptitude because it depends on the field of business you want to pursue. Research shows that interest in becoming entrepreneurs is more influenced by personality factors (Farrukh et al., 2018). The literature review found more than 2000 articles that discussed the influence of personality on entrepreneurship (Kerr et al., 2018). Research by Cardon et al. in (Obschonka et al., 2019) states that the passion for entrepreneurship is in the form of thinking and acting styles - not just interests - that encourage the growth of personal characteristics needed in entrepreneurship. Favretto \& Sartori's research (2010) which compiles the entrepreneurial aptitude test defines aptitude in its tests with a series of personal characteristics. Thus, personality and aptitude factors strongly correlate with enterprising interests.

Conventional interest is also not predicted by any aptitude measured by EAS. Similar results were found by a study done by Pässler et al. (2015). The current study found a very small correlation between conventional interest with perceptual speed aptitude and no correlation with the remaining aptitudes. The interests that do not relate with aptitude are explained by Armstrong et al. (2013) who stated two main reasons: (1) the traditional measurement of cognitive ability did not include the ability needed to work effectively with others; (2) it is possible that cognitive ability is not essential in influencing one's performance in dealing with tasks that stresses the importance of the interpersonal relationship.

However, this study has several limitations in terms of the number and demographic variation of the participants, as well as the unequal spread of vocational interests. Future studies are advised to use other available aptitude tests in Indonesia and explore various other types of aptitudes.

\section{CONCLUSION}

Among university students in Indonesia, the intertwining of vocational aptitude and interest occurs predominantly in investigative interest and numerical aptitude. Individuals with investigative interest refer curious in theory, research and scientific inquiry. Therefore, investigative interest has close relation with aptitude measured by EAS. On the other hand, mastery of numerical aptitude will then influence the development of interest. Career and education counselling, particularly for university students, are therefore expected to take into consideration both the vocational interest and aptitude of the students to have better direction in career-decision making.

\section{REFERENCES}

Ackerman, P. L., \& Beier, M. E. (2003). Intelligence, personality, and interests in the career choice process. Journal of Career Assessment, 11(2), 205-218. https://doi.org/10.1177/1069072703011002006

Ackerman, P. L., \& Heggestad, E. D. (1997). Intelligence, personality, and interests: Evidence for overlapping traits. Psychological Bulletin, 121(2), 219-245. https://doi.org/10.1037/00332909.121.2.219

Armstrong, P. I., Su, R., \& Rounds, J. (2013). Vocational interests. In The Wiley-Blackwell Handbook of Individual Differences (Issue January 2011, pp. 608-631). Wiley-Blackwell.

https://doi.org/10.1002/9781444343120.ch23 
Arulmani, G. (2014). Handbook of career development. In G. Arulmani, A. J. Bakshi, F. T. L. Leong, \& A. G. Watts (Eds.), International and cultural psychology, Handbook of career development : International perspective. Springer New York. https://doi.org/10.1007/978-1-4614-9460-7

Ashton, M. C. (2018). Vocational interests. In Individual Differences and Personality (Issue 2006, pp. 283-301). Elsevier. https://doi.org/10.1016/B978-0-12-809845-5.00011-1

Carson, A. D. (1996). Aptitudes across Holland's types: Implications for school-based counsellors. McGill Journal of Education, 31(3), 319-332. https://mje.mcgill.ca/article/view/8319

Carson, A. D. (1998a). The integration of interests, aptitudes, and personality traits: A test of Lowman's Matrix. Journal of Career Assessment, 6(1), 83-105. https://doi.org/10.1177/106907279800600106

Carson, A. D. (1998b). The relation of self-reported abilities to aptitude test scores: A replication and extension. Journal of Vocational Behavior, 53(3), 353-371. https://doi.org/10.1006/jvbe.1998.1641

Cubico, S., Bortolani, E., Favretto, G., \& Sartori, R. (2010). Describing the entrepreneurial profile: the entrepreneurial aptitude test (TAI). International Journal of Entrepreneurship and Small Business, 11(4), 424. https://doi.org/10.1504/IJESB.2010.036295

Darcy, M., \& Tracey, T. J. G. (2003). Integrating abilities and interests in career choice: Maximal versus typical assessment. Journal of Career Assessment, 11(2), 219-237. https://doi.org/10.1177/1069072703011002007

Domino, G., \& Domino, M. L. (2006). Psychological testing an introduction. Cambridge University Press.

Farrukh, M., Alzubi, Y., Shahzad, I. A., Waheed, A., \& Kanwal, N. (2018). Entrepreneurial intentions. Asia Pacific Journal of Innovation and Entrepreneurship, 12(3), 399-414. https://doi.org/10.1108/APJIE-01-2018-0004

Foutch, H., McHugh, E. R., Bertoch, S. C., \& Reardon, R. C. (2014). Creating and using a database on Holland's theory and practical tools. Journal of Career Assessment, 22(1), 188-202. https://doi.org/10.1177/1069072713492947

Handarini, D. M. (2019). Kontribusi faktor-faktor non-kognitif pada prestasi belajar siswa sekolah menengah pertama. Psychology, Evaluation, and Technology in Educational Research, 1(2), 62. https://doi.org/10.33292/petier.v1i2.22

Holland, J. L. (1985). Making vocational choices : A theory of vocational personalities and work environment. Prentice-Hall, Inc.

Kennelly, E., Sargent, A., \& Reardon, R. (2018). RIASEC Literature from 1953-2016: Bibliographic references to Holland's theory, research, and applications (Technical report No. 58). In Career.Fsu.Edu (Vol. 1, Issue 58). https://doi.org/10.17125/fsu.1519670557

Kerr, S. P., Kerr, W. R., \& Xu, T. (2018). Personality traits of entrepreneurs: A review of recent literature. Foundations and Trends® in Entrepreneurship, 14(3), 279-356. https://doi.org/10.1561/0300000080

Klein, C. (2009). What Do we know about interpersonal skills? A meta-analytic examination of antecedents, outcomes, and the efficacy of training [University of Central Florida]. https://stars.library.ucf.edu/etd/3950/

Komarraju, M., Ramsey, A., \& Rinella, V. (2013). Cognitive and non-cognitive predictors of college readiness and performance: Role of academic discipline. Learning and Individual Differences, 24, 103-109. https://doi.org/10.1016/j.lindif.2012.12.007

Lent, R. W., Brown, S. D., \& Hackett, G. (1994). Toward a unifying social cognitive theory of career and academic interest, choice, and performance. Journal of Vocational Behavior, 45(1), 79-122. https://doi.org/10.1006/jvbe.1994.1027

Leong, F. T. L. (2008). Encyclopedia of counseling. SAGE Publications Inc.

Lowman, R. L. (1993). The inter-domain model of career assessment and counseling. Journal of Counseling \& Development, 71(5), 549-554. https://doi.org/10.1002/j.15566676.1993.tb02240.x 
Ludwikowski, W. M. A. (2014). Ability assessment and vocational outcomes: the impact of utilizing an ability measure in predicting choice, aspirations, and satisfaction [Iowa State University]. https://lib.dr.iastate.edu/etd/13224/

Metz, A. J., \& Jones, J. E. (2013). Ability and aptitude assessment in career counseling. In S. D. Brown \& R. W. Lent (Eds.), Career development and counseling: Putting theory and research to work (pp. 449-476). Wiley Online Library.

Obschonka, M., Moeller, J., \& Goethner, M. (2019). Entrepreneurial passion and personality: The case of academic entrepreneurship. Frontiers in Psychology, 9(JAN), 1-15. https://doi.org/10.3389/fpsyg.2018.02697

Pässler, K., Beinicke, A., \& Hell, B. (2015). Interests and intelligence: A meta-analysis. Intelligence, 50, 30-51. https://doi.org/10.1016/j.intell.2015.02.001

Randahl, G. J. (1991). A typological analysis of the relations between measured vocational interests and abilities. Journal of Vocational Behavior, 38(3), 333-350. https://doi.org/10.1016/00018791(91)90034-J

Silvia, P. J. (2006). Exploring the psychology of interest. Oxford University Press.

Stevens, J. P. (2009). Applied multivariate statistics for the social sciences (5th ed.). Routledge.

Thompson, B. (1984). Canonical correlation analysis: Uses and interpretation. Sage.

Thompson, B. (2015). Canonical correlation analysis. In B. S. Everitt \& D. C. Howell (Eds.), Encyclopedia of Statistics in Behavioral Science (Vol. 1, pp. 265-304). John Wiley \& Sons, Ltd. https://doi.org/10.1002/9781118762547.ch10

Widiana, H. S. (2008). Adaptasi tes employee aptitude survey (EAS). Universitas Gadjah Mada.

Widiana, H. S. (2012). Validitas kriteria subtes EAS 4 ketelitian dan kecepatan visual. Humanitas Indonesian Psychological Journal, 6(2), 170-181. 